\title{
Assessing soil erosion and control factors by the radiometric technique in the Boussouab catchment, Eastern Rif, Morocco
}

\author{
Abdelhamid SADIKI ${ }^{1}$, Ali FALEH ${ }^{2}$, Ana NAVAS ${ }^{3}$ \& Saidati BOUHLASSA ${ }^{4}$ \\ ${ }^{1}$ Department of Geology, Faculty of Sciences, Dhar Mahraz, Fes, Morocco \\ ${ }^{2}$ Department of Geography, Faculty of Letters, Saiss, Route Imouzzer, Fes, Morocco \\ ${ }^{3}$ Department of Soil Science, Estación Experimental de Aula Dei, CSIC. Apartado \\ 202.50080 Zaragoza, Spain \\ ${ }^{4}$ Laboratory of Radiochemistry, Faculty of Sciences, Rabat, Morocco,
}

\section{Abstract}

In the Eastern Rif of N Morocco, soil conservation is seriously threatened by water erosion. Large areas of soil have reached an irreversible state of degradation. In this study, the ${ }^{137} \mathrm{Cs}$ technique was used to quantify erosion rates and identify the main factors involved in the erosion process based on a representative catchment of the Eastern Rif. To estimate erosion rates in terms of the main factors affecting soil losses, samples were collected taking into account the lithology, slope and land use

\footnotetext{
${ }^{1}$ Correspondant author, e mail : sadiki_a@yahoo.fr , fax : 21255733405

² falehali2001@yahoo.fr

3 anavas@eead.csic.es

${ }^{4}$ bouhlass@fsr.ac.ma
} 
along six selected transects within the Boussouab catchment. The transects were representative of the main land uses and physiographic characteristics of that Rif sector. The reference inventory for the area was established at a stable, well preserved, matorral site (value of $4250 \mathrm{~Bq} \mathrm{~m}^{-2}$ ). All the sampling sites were eroded and ${ }^{137} \mathrm{Cs}$ inventories varied widely (between 245 and $3670 \mathrm{~Bq} \mathrm{~m}{ }^{-2}$ ). The effective soil losses were also highly variable (between 5.1 and $48.8 \mathrm{t} \mathrm{ha}^{-1} \mathrm{yr}^{-1}$ ). Soil losses varied with land use. The lowest average values were on matorral and fallow land (10.5 and $15.2 \mathrm{t} \mathrm{ha}^{-1} \mathrm{yr}^{-1}$, respectively) but much higher with alfa vegetation or cereal crops (31.6 and $27.3 \mathrm{t} \mathrm{ha}^{-1} \mathrm{yr}^{-1}$, respectively). The highest erosion rate was on a badland transect at the more eroded part of the catchment, with rates exceeding $40 \mathrm{t}$ $\mathrm{ha}^{-1} \mathrm{yr}^{-1}$ and reaching a maximum of $48.8 \mathrm{t} \mathrm{ha}^{-1} \mathrm{yr}^{-1}$. The average soil losses increased by more than $100 \%$ when the slope increased from $10^{\circ}\left(17.7 \mathrm{t} \mathrm{ha}^{-1} \mathrm{yr}^{-1}\right)$ to $25^{\circ}(40.8$ $\left.\mathrm{t} \mathrm{ha}^{-1} \mathrm{yr}^{-1}\right)$. Similar results were obtained when comparing erosion rates in soils that were covered by matorral with respect to those under cultivation. Lithology was also a key factor affecting soil loss. Soils on marls were more erodible and the average erosion rates reached $29.36 \mathrm{t} \mathrm{ha}^{-1} \mathrm{yr}^{-1}$, which was twice as high as soils on the glacis and old fluvial terraces (average rates of $14.98 \mathrm{t} \mathrm{ha}^{-1} \mathrm{yr}^{-1}$ ). The radiometric approach was very useful to quantify erosion rates and to examine the pattern of soil movement. The analysis of main erosion factors can help to promote rational soil use and establish conservation strategies in the study area.

Key words: soil erosion, ${ }^{137}$ Cs, erosion factors, anthropogenic impact, physiography, Rif, Morocco 


\section{Introduction}

There is a severe risk of desertification in the Rif range (NE Morocco). A combination of factors such as soil erodibility, topography, climate and land use interact to trigger erosion processes that are very intense, especially in mountainous areas. In recent decades, anthropogenic impacts have played an important role in the loss of fertile soil, thus threatening the conservation of soil resources. In that area, soils are poorly developed in general while deforestation and overgrazing have accelerated the erosion process. Intense soil degradation by water erosion also leads to important socioeconomic damage. On the field scale, the fine fractions of soil decrease and soil nutrients are depleted, which decreases soil fertility. Other effects, such as the decrease in infiltration rates, promote disequilibrium in the water soil balance and increase runoff. On a larger scale (such as catchments and river basins), increase in the runoff coefficient causes devastating floods that have undesirable side effects and damage infrastructure (channels, roads and bridges). Other important indirect impacts are rapid siltation of water bodies, which decreases their storage capacities. The overall degradation of soil resources has serious consequences for stable development in the region (Faleh, 2004).

The ${ }^{137}$ Cs radiometric technique was used to assess the erosion produced by runoff and rills since it is useful to quantify soil erosion in a variety of environments around the world. From the first studies (Ritchie et al., 1974, Walling et al. 1986; Martz and De Jong, 1987; Loughran et al., 1990; Ritchie and McHenry, 1990) to more recent works (e.g. Banis et al., 2004, Navas et al., 2005), the history of the successful application of this technique extends over the last 30 years. 
Assessment of erosion in semiarid Mediterranean regions (Navas and Walling, 1992 ; Quine et al., 1994, Soto and Navas, 2004) also demonstrate the potential of this technique to describe soil movement in highly fragile environments. In Morocco, studies using fallout ${ }^{137}$ Cs have been conducted more recently by Moukhchane (1999), Bouhlassa et al. (2000) and Faleh et al. (2005 a,b).

In the Boussouab catchment, the key role of vegetation cover, topography and type of parent materials on which soils are developed has been demonstrated using classical methods and empirical equations (Sadiki, 2005). The objective of this paper was to apply an alternative and reliable technique with a physical basis to measure the effect of the above mentioned factors on soil loss. A soil survey was designed to establish representative transects, taking into consideration land use, slope and lithology along selected transects in a characteristic catchment of the fragile environment in the Eastern Rif.

\section{The study area}

The Boussouab catchment in the Eastern Rif (NE Morocco), located some 40 km $\mathrm{N}$ of Taza city, extends over a surface area of 25,220 ha. This middle mountain area with altitudes ranging from $625 \mathrm{~m}$ to $1622 \mathrm{~m}$, is characterized by a hilly type landscape. The structural divisions are the Meso-Rif, the Pre-Rif and the Foreland (Figure 1).

The Meso-Rif is composed of friable and light rocks such as dark shales, white marls, limestones with marls and decimetric strata of marls embedded with silex limestones. The Pre - Rif extends in the catchment from NE to SW, its internal part is a flysch composed by sandy schists, whereas the external part occupies a larger area made of Pre- Rif nappe. This is a thick and homogenous sequence of blue marls. On these 
allochtone formations there are synclinals post-nappes of Tortonian age composed of a thick sequence of sandy strata. The Foreland is formed by the sandy-carbonatic massif of Terni-Mezgout. The sillon South - Rif is a basin filled with conglomerates, calcarenites and marls that separates the massif of Terni-Mezgout from the Rif range.

The climate is semiarid to arid type with an average annual rainfall ranging between $150 \mathrm{~mm}$ in the South at Anguied and $350 \mathrm{~mm}$ in the North at Tizi Ousli. Rainfalls are often short but very intense. Their distribution is irregular both in time and in space and most of the water courses are ephemeral, apart from the Boussouab River that drains the catchment.

The natural vegetation in the area is within the arid - semiarid bioclimatic stage. Matorral is the predominant vegetation cover, with important degradation features. The most common species are Alep pine (Pinus halepensis), juniper (Juniperus communis) and thuya (Thuya orientalis), with some Eucalyptus plantations. On the smooth slopes, there is steppe vegetation composed by shrubs of alfa (Stypa tenassissima) and Artemisa $s p$. On the flat valley floor, soils are cultivated for cereals that have very low yields and are left fallow once every two years.

\section{Materials and Methods}

The fallout of ${ }^{137} \mathrm{Cs}$ was especially intense in 1963 and the radioisotope remains fixed to soil particles, especially at upper soil layers. Using this artificial radiotracer, the soil movement can be traced and erosion and aggradation rates can be estimated. The measured inventories are compared with the reference sites where soil stability is adequate to preserve the initial activities per surface area from the maximum ${ }^{137} \mathrm{Cs}$ fallout (Ritchie et al., 1974). 
A soil sampling scheme was established to select representative transects of the main soil characteristics, slope and land use in the study area (Figure 1). The soil samples were collected along six transects following the slope direction, and sampling sites were $10 \mathrm{~m}$ apart. A $7 \mathrm{~cm}$ manual corer was used to extract the $30 \mathrm{~cm}$ deep soil samples, thus ensuring that the whole radioisotope profile was retained (Faleh et al., 2005 a). A total of 4 transects (T1, T2, T3, T4) were taken on marls substrate that had different land uses and slopes. The T1 (7 cores, C1 - C7) was on fallow land, T2 (7 cores, C8 - C14) on cereal crops, T3 (7 cores, C15 - C21) under shrubs cover of alfa and T4 (3 cores, C34 - C36) on bare soils at a highly degraded slope of badlands. Another two transects (T5, T6) were taken on soils developed on a Quaternary formation that is a combination of glacis and old fluvial terraces. Transect 5, T5 (6 cores, C22 - C27), was on a fairly dense "matorral”, whereas T6 (6 cores, C28 - C33) was on fields with cereal crops. A stable site that was almost level and had well preserved natural vegetation was chosen for sampling as reference for the study area, and a composite sample was created (T).

The 36 bulk cores were sectioned at $5 \mathrm{~cm}$ intervals and samples were treated following standard methods (Walling and Quine, 1991) prior to analysis for ${ }^{137} \mathrm{Cs}$ by gamma spectrometry. Samples were air-dried, ground and passed through a $2 \mathrm{~mm}$ sieve. The ${ }^{137}$ Cs activities were measured using a high resolution, low background, low energy, hyperpure coaxial gamma-ray detector coupled to an amplifier and multichannel analyser. The detector was shielded to reduce background and calibrated using standard samples in the same geometry as the measured samples. Gamma emissions of ${ }^{137} \mathrm{Cs}$ (662 keV line in $\mathrm{Bq} \mathrm{kg}{ }^{-1}$ air-dry soil) were measured on 222 sub-samples. Counting times were around $30000 \mathrm{~s}$ and the analytical precision of the measurements was approximately $\pm 6 \%$. 
Calibration of ${ }^{137}$ Cs values can be approached by using mass-balance models (Walling and He, 1997), allowing to estimate erosion rates. For cultivated soils, the mass balance model I (simplified mass balance model) by Zhang et al. (1990) was used.

$$
Y=\frac{10 d B}{P}\left[1-\left(1-\frac{X}{100}\right)^{1 /(t-1963)}\right]
$$

Where $\mathrm{Y}=$ mean annual soil loss $\left(\mathrm{t} \mathrm{ha}^{-1} \mathrm{yr}^{-1}\right)$; $\mathrm{D}=$ depth of plough or cultivation layer $(\mathrm{m}) ; \mathrm{B}=$ bulk density of soil $\left(\mathrm{kg} \mathrm{m}^{-3}\right) ; \mathrm{X}=$ percentage reduction in total ${ }^{137} \mathrm{Cs}$ inventory; $\mathrm{P}=$ particle size correction factor.

For the uncultivated soils, a profile distribution model (Zhang et al., 1990; Walling and Quine, 1991) was used.

$$
Y=\frac{10}{(t-1963) P} \ln \left(1-\frac{X}{100}\right) h_{0}
$$

Where $\mathrm{Y}=$ annual soil loss $\left(\mathrm{t} \mathrm{ha}^{-1} \mathrm{yr}^{-1}\right) ; \mathrm{T}=$ year of sampling $(\mathrm{yr}) ; \mathrm{X}=$ percentage ${ }^{137} \mathrm{Cs}$ loss in total inventory in respect to the local reference value (defined as $\left.X=\frac{A_{r e f}-A_{u}}{A_{r e f}} \times 100\right) ; \mathrm{A}_{\mathrm{u}}=$ measured total ${ }^{137}$ Cs inventory at the sampling point $(\mathrm{Bq}$ $\left.\mathrm{m}^{-2}\right) . \mathrm{P}=$ particle size correction factor.

\section{Results and Discussion}

The reference inventory in the Boussouab catchment was established in a relatively dense matorral with a high percentage of its surface covered by alfa and the site was almost level. The total inventory was $4250 \mathrm{~Bq} \mathrm{~m}^{-2}$, with a typical exponential 
decay of the radioisotope with depth (Figure 2). The ${ }^{137}$ Cs was concentrated in the upper part of the soil profile (more than $70 \%$ in the first $15 \mathrm{~cm}$ ). As seen in Table 1, the reference inventories in Morocco are quite variable, depending on physiographic characteristics but especially differences in annual rainfall.

A summary of the physiographic characteristics of the transects, together with ${ }^{137} \mathrm{Cs}$ inventories and estimates of erosion rates at the sampling sites is presented in Table 2. The average ${ }^{137} \mathrm{Cs}$ inventory in the study area was $1748 \mathrm{~Bq} \mathrm{~m}{ }^{-2}(\mathrm{sd}=1044)$ and the estimated erosion rate was around 24. $6 \mathrm{t} \mathrm{ha}^{-1} \mathrm{yr}^{-1}$, ( $\left.\mathrm{sd}=11.7\right)$ largely exceeding the rates required to maintain the soil resource. Therefore, there is a general risk of losing this non-renewable resource in the area.

The ${ }^{137}$ Cs inventories varied widely at the sampling sites ranging from 245 to $3672 \mathrm{~Bq} \mathrm{~m}{ }^{-2}$.Compared with the reference inventory for the study area, those values represent a range of ${ }^{137} \mathrm{Cs}$ loss between $95 \%$ and $14 \%$, respectively. The estimation of erosion rates by mass balance and profile models for the cultivated and uncultivated soils were also quite variable, with minimum and maximum values of 5.1 and $48.8 \mathrm{t} \mathrm{ha}^{-1}$ $\mathrm{yr}^{-1}$, respectively.

For each of the transects, the average ${ }^{137}$ Cs inventories ranged between 352 and $2958 \mathrm{~Bq} \mathrm{~m}{ }^{-2}$ and the average soil losses between 10.5 and $46.4 \mathrm{t} \mathrm{ha}^{-1} \mathrm{yr}^{-1}$. The lowest erosion rates were in soils on glacis at the matorral transect (T5) and the highest were in soils on marls of the transect cultivated for cereals (T2) and in the bare soils of the badland transect (T4). Erosion rates were also quite high in soils with alfa vegetation on marls. Since the six transects have similar climatic conditions, the large variability in erosion rates must be explained by other physiographic factors, such as parent materials, land use and topography. 
As seen in Figures 3 and 4, the ${ }^{137} \mathrm{Cs}$ depth distribution differed markedly between the matorral (T5) and badland transects (T4). These are the most different transects in the study area, the former being better preserved and the latter more degraded. In the matorral transect $\mathrm{T} 5,{ }^{137} \mathrm{Cs}$ decays exponentially along the soil profile. The site at the head transect is quite stable, but along the transect, increasing slope values increase the soil movement down-slope and erosion rates double that at the top position. The depletion of ${ }^{137} \mathrm{Cs}$ in the upper $5 \mathrm{~cm}$ indicates that erosion mainly affects the soil surface, and that it does not progress further at deeper layers. At the badland transect T4, ${ }^{137}$ Cs was largely depleted along the soil profile and the radioisotope only appeared in the upper $5 \mathrm{~cm}$. Thus, it appears that soils were much better preserved under the matorral. This has also been found in soils developed on marls in a semiarid environment with similar rainfall patterns (Quine et al., 1994).

The fallow transect (T1) on marls had more homogeneous ${ }^{137}$ Cs depth profiles. This is due to occasional tillage, mainly within the first $20 \mathrm{~cm}$ what is the normal depth of ploughing. There was some ${ }^{137}$ Cs depletion in the upper soil layers. In strong contrast, there was only little ${ }^{137} \mathrm{Cs}$ in the first $10 \mathrm{~cm}$ in the depth profiles along transect T2, with cereal crops. Similarly, the ${ }^{137} \mathrm{Cs}$ depth distribution of T2 was quite different from the other cereal transect (T6) on the glacis substrate.

Along the alfa transect (T3), all sites were highly eroded, as indicated by the ${ }^{137}$ Cs depth distribution. In 5 of the 7 sites, the radioisotope only appeared within the first $10 \mathrm{~cm}$ and inventories were considerably depleted as they were almost less than half of those found at the matorral transect T5. Below $10 \mathrm{~cm},{ }^{137} \mathrm{Cs}$ is almost zero and just one site shows a deeper profile in which the depletion of ${ }^{137} \mathrm{Cs}$ is also very high.

The data of the six transects were grouped separately to create homogeneous sets having similar substrate, slope or land use. Considering the slope factor, for the same 
marls substrate and land use (alfa), along the alfa transect T3, erosion increases for increasing slope values (Table 2). However, the sites located at the top and bottom positions of the slope that are flatter that the rest of the sites along the slope, are less eroded. As shown in Figure 3, soil losses on $15^{\circ}$ slope sites in T3 were around $25 \mathrm{t} \mathrm{ha}^{-1}$ $\mathrm{yr}^{-1}$, whereas at $25^{\circ}$ slope sites, average soil loss was around $35 \mathrm{t} \mathrm{ha}^{-1} \mathrm{yr}^{-1}$. Hence, soil loss increased by approximately $40 \%$ for a slope increase of $10^{\circ}$. Therefore, slope is also one of the main factors responsible for variation of soil losses in the studied catchment. This agrees with findings by Zhang et al. (2003) that also used the radiometric technique to assess soil erosion rates on sloping, cultivated land and flat terraces in the Upper Yangtze River Basin, China. In spite of the physiographic differences they also found that sloping cultivated fields suffer very severe soil erosion, in strong contrast with terraced fields, and suggest a close relationship between erosion, soil texture and slope gradient.

When considering soils developed on the same substrate and with the same slope values, soil losses varied largely in terms of land use. As shown in Figure 4, the soils on the glacis of the $10^{\circ}$ slope transect $\mathrm{T} 5$ under matorral vegetation has erosion rates around $10.5 \mathrm{t} \mathrm{ha}^{-1} \mathrm{yr}^{-1}(\mathrm{sd}=2.7)$. However, in soils cultivated for cereals at the $10^{\circ}$ slope transect T6 (also on glacis materials), the erosion rates were $19.4 \mathrm{t} \mathrm{ha}^{-1} \mathrm{yr}^{-1}$ (sd = 4.7). Therefore, in 40 years the cultivated soils have lost almost double the amount of soil as under matorral. The main role of vegetation in protecting the soil surface and, conversely, cultivation as a key factor triggering erosion in semiarid areas, was also outlined in a nearby study area (Faleh et al., 2005 a) and in a Spanish catchment (Quine et al., 1994). In south-eastern Brazil, Guimaraes et al. (2003) also found that soil movement was related to slope, land use, and conservation practices, based on ${ }^{137} \mathrm{Cs}$ estimates. 
Those results demonstrate the negative impact of land use changes, such as deforestation of highly fragile soils that are later cultivated. In the study area, there is an increasing trend to transform the rangeland on steep slopes into grazing areas or cultivated fields. Those practices are the main factors triggering erosion and the surfaces with increasing risk of erosion have also been extending rapidly over the last decades. All these negative impacts under intense anthropogenic pressure endanger the sustainability of agroecosystems in the Rif. Soils quickly lose their fertile horizons and reach stages of very low productivity. Other undesirable effects are the conversion of transformed areas into net suppliers of sediments that are then exported through the drainage system, thus contributing to the siltation of dams and reservoirs in the region.

For soils with the same slope $\left(10^{\circ}\right)$ and land use (cultivated for cereals) (Table 2) the largest soil losses occurred in soils developed on marls, that lost around $34 \mathrm{t} \mathrm{ha}^{-1} \mathrm{yr}^{-1}$ on average. Those rates almost double what was measured in soils on the Quaternary glacis-terrace (average values of $19 \mathrm{t} \mathrm{ha}^{-1} \mathrm{yr}^{-1}$ ). Schoorl et al. (2004) assessed the effects of lithology, slope morphology and land use on steep Mediterranean slopes and found important differences in radionuclide concentrations depending on lithology. Although the rocks in their study area were very different from the Rif, the main effect of the difference in clay mineralogy can be a reason for those differences. Those authors also observed that higher ${ }^{137}$ Cs inventories are associated with higher percentages of vegetation cover, as in this study. On the marls substrate, the soils cultivated for cereals had similar erosion rates when the slope was $15^{\circ}$, so for that range of slopes $\left(10^{\circ}-15^{\circ}\right)$ cultivation was the main erosion factor.

Therefore, the ${ }^{137} \mathrm{Cs}$ inventories and soil losses varied with the substrate, land use and slope. Summary statistics in Table 3 illustrate the differences in terms of the factors considered in this study. A one-way analysis of variance showed a significant 
difference $(\mathrm{P}<0.05)$ between the means for ${ }^{137} \mathrm{Cs}$ inventories and erosion rates from soils on the marls and soils on the glacis-terrace materials. There were also significant differences between the means for erosion rates from bare soils on marls and the remaining land uses. When considering slope as the variation factor, increases of $5^{\circ}$ in slope significantly affected the variation in erosion rates.

In the Boussouab catchment, rational land use is very important for the control and conservation of soils. Moreover, slope deforestation, overgrazing, poor soil management and other soil abuses enhance the fragility of this environment and substantially increase erosion rates.

\section{Conclusion}

The ${ }^{137}$ Cs technique helped to trace soil movement in the last 40 years. The comparison between the reference inventory for the area and the measured inventories at the sampling sites with different slope values, parent materials and land uses reflects a large variability. The more degraded cultivated soils on marls of steeper slopes were 10 times more eroded than the best preserved soils under matorral, gentle slopes and glacis-terrace substrate.

The main cause of erosion in the study area was anthropogenic impact, especially when the natural vegetation was eliminated and the land used for crops. Erosion rates in cultivated land were twice as high as land with matorral. Where anthropogenic impact was minimal, slope appeared to be the main cause of erosion. Finally, another important factor was substrate, because marls are more erodible than glacis materials, the erosion rates on marls substrate doubled that on Quaternary glacis terraces. 
Because of the fragility of this environment and its risk of accelerated erosion under increasing anthropogenic pressure, it is necessary to establish conservation measures to protect the natural vegetation and delimit areas for cultivation to more gentle surfaces.

From our results and the relative importance of the studied factors on triggering soil erosion, the following recommendations should be taken into consideration. Urgent action is required to protect the soils developed on marls because they are highly erodible. In areas with some vegetation cover and depending on its conservation, reforestation is recommended with trees, for forest areas, or with autochthonous alfa species, in the areas where shrubs are predominant. This will increase the soil surface protected by the vegetation cover and reduce the splash and consequent detachment of soil particles. Increasing root density will favour water infiltration and improving soil structure will help maintain soil particles within the soil matrix. Since slopes in the study area were quite steep, constructing furrows along contour strips will decrease the erosive impact of runoff by limiting its speed.

For areas cultivated for cereals it is highly recommended to encourage the participation of inhabitants and promote tillage following the contour lines. Furthermore, implementing borders to enclose the cultivated fields will help to retain the detached soil particles. Such furrow boundaries could be planted with fruit trees adapted to a semiarid climate such as olive, fig or almond trees.

For areas where erosion has reached an irreversible stage and vegetation growth is extremely complicated, mechanical intervention is required, such as wall construction to limit erosion of bare surfaces which are the main sources of sediments that are then transported out of the catchments and end up in reservoirs or other water bodies in the lowlands, thus contributing to rapid siltation. 
The preservation of this environment is the only guarantee to stop desertification since the Rif and its woodlands constitute a natural barrier. Furthermore, it is necessary to identify areas that supply sediments to design action plans and soil best management practices to limit the generation of sediments and its transport to water bodies, thus reducing water storage capacities and water quality.

\section{Acknowledgements}

This work was funded by the bilateral projects 2004MA-1005 and 18304-RM from the Agencia de Cooperación Interuniversitaria and the CICYT projects RADIERO (REN2002-02702/GLO) and REM (CGL2005-02009/BTE).

\section{References}

Banis, YN., Bathurst, JC., Walling, DE., 2004. Use of caesium-137 data to evaluate SHETRAN simulated long-term erosion patterns in arable lands. Hydrol. Proc.18, 1795-1809.

Bouhlassa, S., Moukhchane, M., Aiachi, A., 2000. Estimates of soil erosion and deposition of cultivated soil of Nakhla watershead, Morocco, using ${ }^{137}$ Cs technique and calibration models Acta Geol. Hisp. 35, 239-249.

El Katmour, H., 2004. Mutations spatiales et leurs impact sur la dynamique actuelle dans le bassin versant de Tigrigra (Moyen Atlas) Doctorat nationale, Université Mohamed V, Rabat, pp. 327. 
Faleh, A., 2004. Quantification qualitative et quantitative et modélisation mathématique de l'érosion hydrique dans les bassins versant d'Aknoul et Merkat (Prérif central et oriental). Thèse d’Etat, Faculté des Lettres et des Sciences humaines d’Oujda, pp. 372 (en arabe).

Faleh, A., Bouhlassa, S., Sadiki, A., Navas, A., Aboutaher, A., 2005 a. Aplicación de la técnica de ${ }^{137}$ Cs para evaluar la erosión en la cuenca del río Abdelali (norte de Marruecos). Cuat. y Geomorfol. 19, 15-22.

Faleh, A., Navas, A., Sadiki, A. 2005 b. Erosion and dam siltation in a Rif catchment (Morocco). In: Sediment Budgets 2 (Horowitz, A.J. \& Walling, D.E. Eds.) IAHS Publ. $n^{\circ}$ 292: 58-64.

Guimaraes , M.F., Nascimento, V.F., Ritchie, J., 2003 Application of cesium-137 in a study of soil erosion and deposition in Southeastern Brazil. Soil Sci. 168, 45- 53.

Loughran, R.J., Campbell, B.L., Elliot, G.L., 1990. The calculation of net soil loss using Caesium-137. In: Boardman, J., Foster I.D.L., Dearing, J.A., (Eds.), Soil erosion n Agricultural Land, Ed. Wiley and Sons, Chichester, pp. 119 - 125.

Martz, L.W., De Jong, E., 1987. Using cesium-137 to assess the variability of net soil erosion and its association with topography in a Canadian prairie landscape. Catena 14, 439-451.

Moukchane, M., 1999. Contribution à l'étude de l'érosion hydrique dans le Rif occidental. Applications des méthodes expérimentales du ${ }^{137} \mathrm{Cs}$ et de la susceptibilité magnétique aux bassins versant Nakhla, Elhachef et Smir . Thèse d'état Faculté des Sciences de Tétouan, Maroc, pp. 260.

Navas, A., Walling, D.E., 1992. Using caesium-137 to assess sediment movement on slopes in a semi-arid upland environment in Spain. In: Erosion, Debris Flows and Environnment in Mountain Regions, IAHS Publ. nº. 209, 129-138. 
Navas, A., Machín, J., Soto, J., 2005. Assessing soil erosion in a Pyrenean mountain catchment using GIS and fallout ${ }^{137}$ Cs. Agr. Ecosyst. \& Environ. 105, 493-506.

Quine, T. A., Navas, A., Walling, D.E., Machín, J., 1994. Soil erosion and redistribution on cultivated and uncultivated land near Las Bardenas in the central Ebro river basin, Spain. Land Dégrad. Rehabil. 5, 41-55.

Ritchie, J.C., McHenry, J.R., Gill, A.C., 1974. Fallout ${ }^{137}$ Cs in the soil and sediments of three small watersheds. Ecology 55, 887-890.

Ritchie, J.C., McHenry, J.R., 1990. Application of radioactive fallout cesium-137 for measuring soil erosion and sediment accumulation rates and patterns: a review. J. Environ. Qual. 19, 215-233.

Sadiki, A., 2005. Estimation des taux d'érosion et de l'état de dégradation des sols dans le bassin versant de l'oued Boussouab, Maroc nord oriental : application du modèle empirique (USLE), de la technique du radio-isotope ${ }^{137} \mathrm{Cs}$ et de la susceptibilité magnétique. Thèse Doctorat d’Etat. Université Mohamed Premier, Oujda pp.320.

Schoorl, J.M., Boix Fayos, C., de Meijer, R.J., van der Graaf, E.R., Veldkamp, A., 2004. The Cs-137 technique applied to steep Mediterranean slopes (Part I): the effects of lithology. Catena.57, 15-34.

Soto, J., Navas, A. 2004. A model of ${ }^{137}$ Cs activity profile for soil erosion studies in uncultivated soils of Mediterranean environments. J. Arid Environ. 59, 719-730.

Walling, D.E., Bradley, S.B., Wilkinson, C.J. 1986. A caesium-137 budget approach to the investigation of sediment delivery from a small agricultural drainage basin in Devon, UK. In: Drainage Basin Sediment Delivery (ed. By R.Hadley) IAHS Publi. 423-435.

Walling, D.E., Quine, T.A., 1991. The use of caesium 137 to investigate soil erosion on arable field in the U.K . - potential applications and limitations. J. Soil Sci. 42, 147165. 
Walling D. E., He Q., 1997. Models for converting ${ }^{137}$ Cs measurements to estimates of soil redistribution rates on cultivated and uncultivated soils. Report to the IAEA as a contribution to IAEA Coordinated Research Programmes on Soil Erosion (D1.50.05) and Sedimentation (F31001). Department of Geography, University of Exeter, UK.

Zhang X., Higgit D. L., Walling D. E., 1990. A preliminary assessment of the potential for using caesium-137 to estimate rates of soil erosion in the Loess Plateau of China. Hydrolog. Sci. J. 35, 267-276.

Zhang, X.B., Zhang, Y.Y., Wen, A.B., Feng, M.Y., 2003. Assessment of soil losses on cultivated land by using the Cs-137 technique in the Upper Yangtze River Basin of China. Soil \& Till. Res. 69, 99-106. 


\section{FIGURE CAPTIONS}

Figure 1. Location and geology of the Boussouab catchment

Figure $2 .{ }^{137}$ Cs reference inventory for the Boussouab catchment

Figure $3 .{ }^{137} \mathrm{Cs}$ depth distribution, inventories and erosion rates at the sampling sites along the transects on marls substrate.

Figure $4 .{ }^{137} \mathrm{Cs}$ depth distribution, inventories and erosion rates at the sampling sites along the transects on glacis - terrace substrate. 
Figure 1

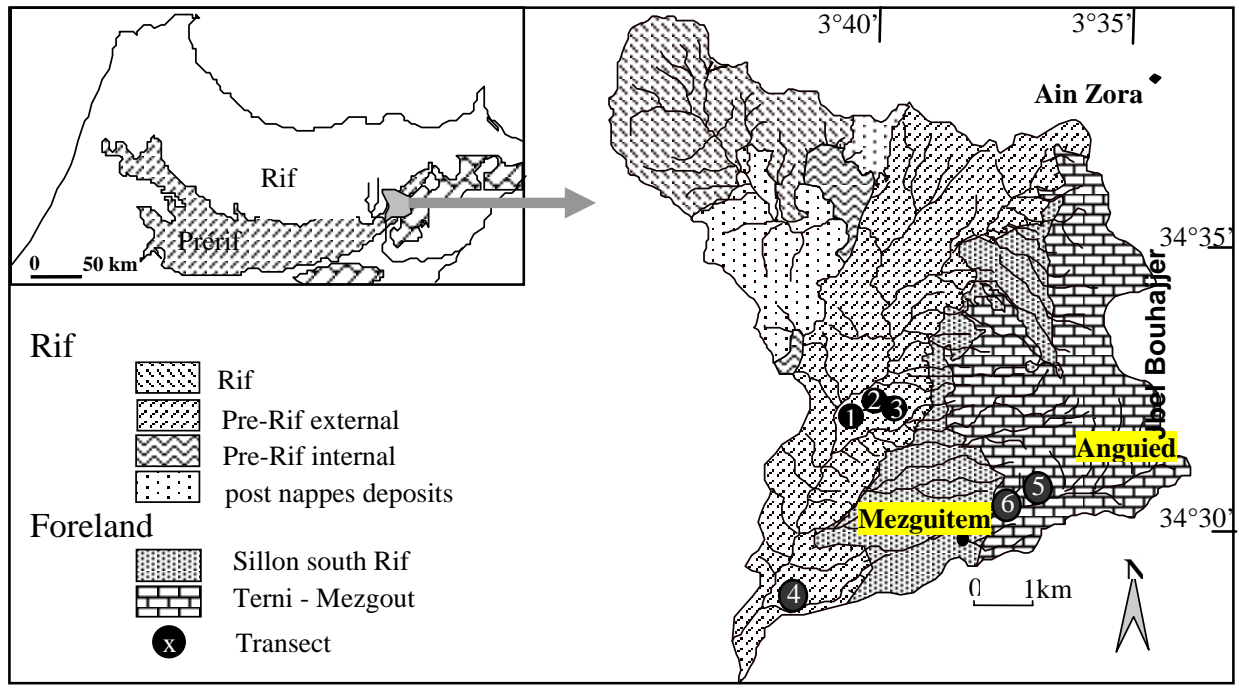


Figure 2

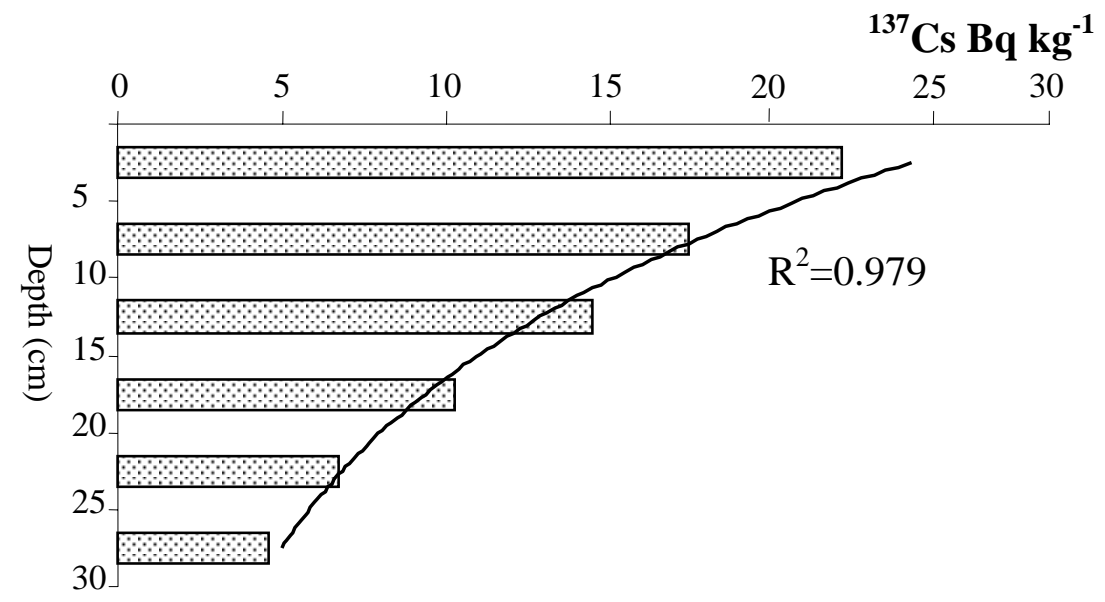


${ }^{137} \mathrm{Cs}$ inventory : $2587 \mathrm{~Bq} \mathrm{~m}{ }^{-2}$

Erosion rate : $15.3 \mathrm{t} \mathrm{ha}^{-1} \mathrm{yr}^{-1}$

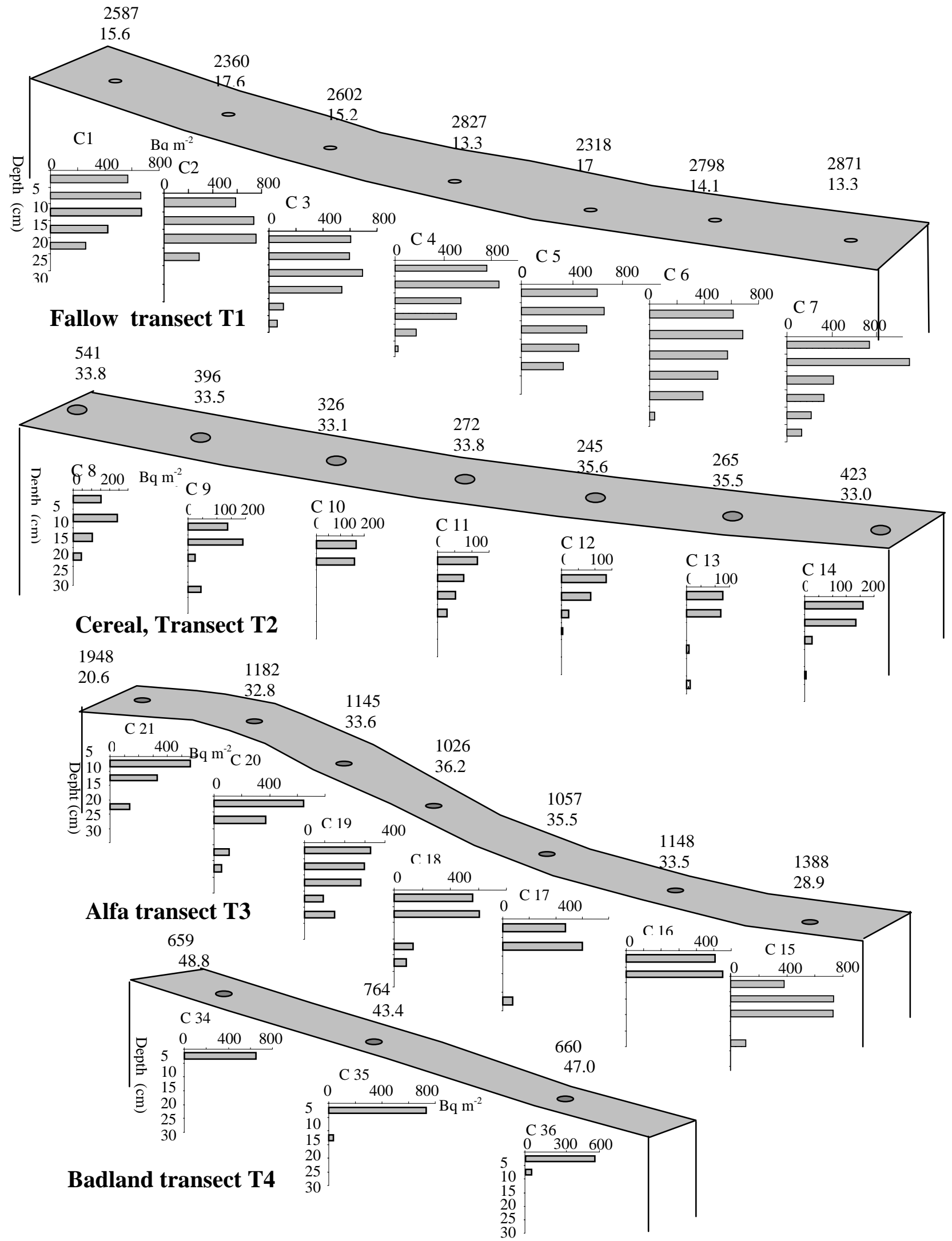


Figure 4

${ }^{137}$ Cs inventory : $3052 \mathrm{~Bq} \mathrm{~m}{ }^{-2}$

Erosion rate : $12.9 \mathrm{t} \mathrm{ha}^{-1} \mathrm{yr}^{-1}$

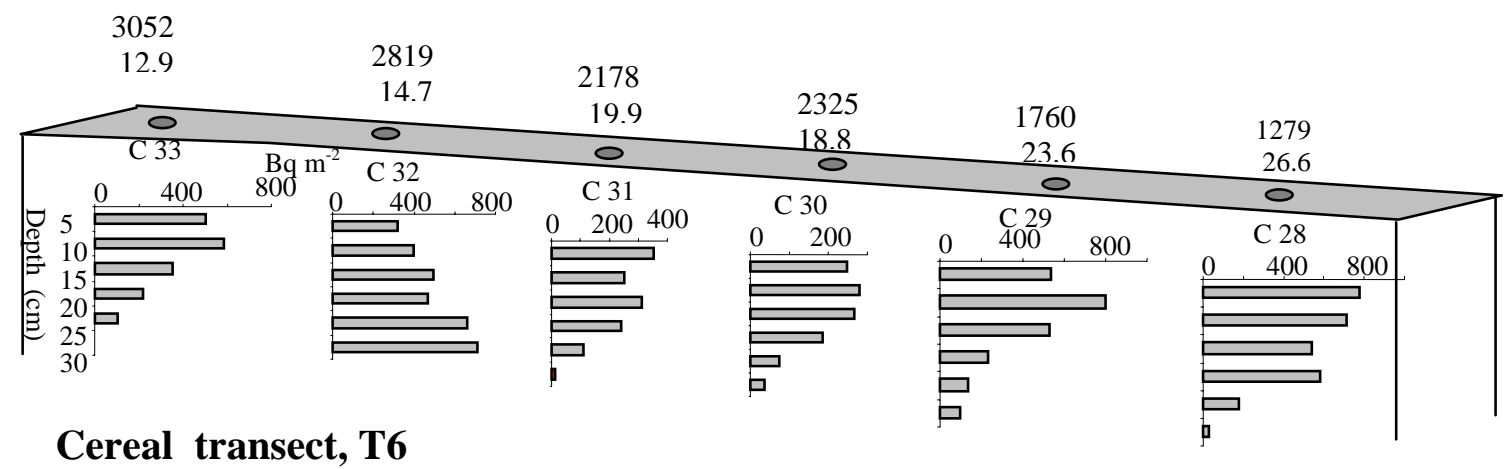

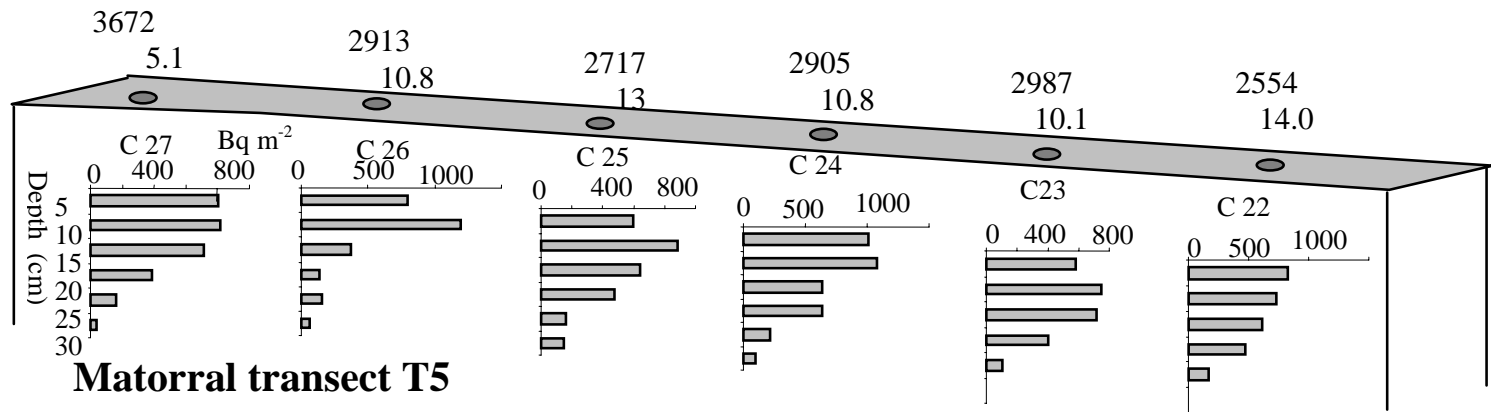


Table 1. Spatial variability of the ${ }^{137}$ Cs reference inventories in Morocco

\begin{tabular}{|c|c|c|}
\hline Area & $\begin{array}{c}{ }^{137} \text { Cs reference } \\
\text { inventory }\left(\mathrm{Bqm}^{-2}\right)\end{array}$ & authors \\
\hline oued Nakhla (Rif occidental & 3250 & Bouhlassa et al. (2000) \\
\hline oued Aknoul (Rif oriental) & 3702 & Faleh (2004) \\
\hline Merkat (Prérif central) & 2802 & Faleh (2004) \\
\hline Oued Tigrigra (Moyen Atlas) & 4491 & El Katmour (2004) \\
\hline Boussouab (Prérif oriental) & 4250 & Sadiki (2005) \\
\hline
\end{tabular}


Table 2. Physiographic characteristics of transects and ${ }^{137}$ Cs inventories and soil losses at the sampling sites.

\begin{tabular}{|c|c|c|c|c|c|c|}
\hline Lithology & Transect & Land use & $\begin{array}{c}\text { Sample } \\
\text { (core) }\end{array}$ & Slope $\left(^{\circ}\right)$ & $\begin{array}{c}{ }^{137} \mathrm{Cs} \\
\text { Inventories } \\
\mathrm{Bq} \mathrm{m}^{-2}\end{array}$ & $\begin{array}{c}\text { Soil losses } \\
\text { t ha }^{-1} \mathrm{yr}^{-1}\end{array}$ \\
\hline \multirow{24}{*}{ marls } & \multirow{7}{*}{$\mathrm{T} 1$} & \multirow{7}{*}{$\begin{array}{l}\text { Fallow } \\
\text { land }\end{array}$} & C1 & 20 & 2587 & 15.6 \\
\hline & & & C2 & 20 & 2360 & 17.6 \\
\hline & & & C3 & 20 & 2602 & 15.2 \\
\hline & & & $\mathrm{C} 4$ & 20 & 2827 & 13.3 \\
\hline & & & C5 & 20 & 2318 & 17.0 \\
\hline & & & C6 & 15 & 2798 & 14.1 \\
\hline & & & $\mathrm{C7}$ & 15 & 2871 & 13.3 \\
\hline & \multirow{7}{*}{$\mathrm{T} 2$} & \multirow{7}{*}{ Cereals } & C8 & 15 & 541 & 33.8 \\
\hline & & & C9 & 15 & 396 & 33.5 \\
\hline & & & C10 & 15 & 326 & 33.1 \\
\hline & & & C11 & 15 & 272 & 33.8 \\
\hline & & & C12 & 15 & 245 & 35.6 \\
\hline & & & C13 & 10 & 265 & 35.5 \\
\hline & & & C14 & 10 & 423 & 33.0 \\
\hline & \multirow{7}{*}{ T3 } & \multirow{7}{*}{ Alfa } & C15 & 15 & 1388 & 28.9 \\
\hline & & & C16 & 20 & 1148 & 33.5 \\
\hline & & & C17 & 25 & 1057 & 35.5 \\
\hline & & & C18 & 25 & 1026 & 36.2 \\
\hline & & & C19 & 25 & 1145 & 33.6 \\
\hline & & & C20 & 20 & 1182 & 32.8 \\
\hline & & & $\mathrm{C} 21$ & 15 & 1948 & 20.6 \\
\hline & \multirow{3}{*}{$\mathrm{T} 4$} & \multirow{3}{*}{ Badland } & C34 & 25 & 660 & 48.8 \\
\hline & & & C35 & 25 & 764 & 43.4 \\
\hline & & & C36 & 25 & 614 & 47.0 \\
\hline \multirow{13}{*}{$\begin{array}{l}\text { Glacis } \\
\text { terrace }\end{array}$} & \multirow{6}{*}{ T5 } & \multirow{6}{*}{ Matorrals } & $\mathrm{C} 22$ & 10 & 2554 & 14.0 \\
\hline & & & C23 & 10 & 2987 & 10.1 \\
\hline & & & C24 & 10 & 2905 & 10.8 \\
\hline & & & C25 & 10 & 2717 & 13.0 \\
\hline & & & C26 & 10 & 2913 & 10.8 \\
\hline & & & $\mathrm{C} 27$ & 10 & 3672 & 5.1 \\
\hline & \multirow{6}{*}{ T6 } & \multirow{6}{*}{ Cereals } & C28 & 10 & 1279 & 26.6 \\
\hline & & & C29 & 10 & 1760 & 23.6 \\
\hline & & & C30 & 10 & 2325 & 18.8 \\
\hline & & & C31 & 10 & 2178 & 19.9 \\
\hline & & & C32 & 10 & 2819 & 14.7 \\
\hline & & & C33 & 10 & 3052 & 12.9 \\
\hline & reference & Forest & $\mathrm{T}$ & level & 4250 & 0.0 \\
\hline
\end{tabular}


Table 3 . Summary statistics for the ${ }^{137}$ Cs inventories and soil losses in function of lithology, land use and slope.

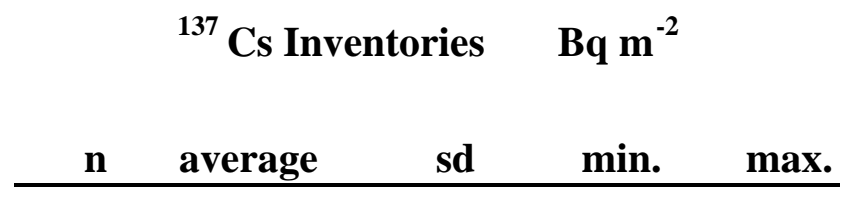

\section{lithology}

marls

glacis -terraces

\begin{abstract}
24
\end{abstract}
1324

2597

948

245

$637 \quad 1279$

2871

land use

fallow

cereals

alfa

matorral

bare soil

$\underline{\text { slope }^{o}}$

10
15
20
25

$\begin{array}{rrrrr}7 & 2623 & 223 & 2318 & 2871 \\ 13 & 1221 & 1068 & 245 & 3052 \\ 7 & 1271 & 321 & 1026 & 1950 \\ 6 & 2958 & 384 & 2554 & 3672 \\ 3 & 679 & 77 & 614 & 764\end{array}$

$\begin{array}{rrrrr}14 & 2275 & 1007 & 265 & 3672 \\ 9 & 1198 & 1093 & 245 & 2871 \\ 7 & 2147 & 691 & 1149 & 2827 \\ 6 & 878 & 226 & 614 & 1145\end{array}$

Soil losses $\mathrm{t} \mathrm{ha}^{-1} \mathrm{yr}^{-1}$

average sd min.

max.

$\begin{array}{rrrr}29,4 & 10,8 & 13,3 & 48,8 \\ 15,0 & 6,2 & 5,1 & 26,7\end{array}$

$\begin{array}{lrrr}15,2 & 1,7 & 13,3 & 17,6 \\ 27,3 & 8,3 & 12,9 & 35,6 \\ 31,6 & 5,4 & 20,6 & 36,2 \\ 10,5 & 3,0 & 5,1 & 14,0 \\ 46,4 & 2,7 & 43,4 & 48,8\end{array}$

$\begin{array}{llrl}17,7 & 9,0 & 5,1 & 35,5 \\ 27,4 & 9,0 & 13,3 & 35,6 \\ 20,7 & 8,6 & 13,3 & 33,5 \\ 40,8 & 6,5 & 33,6 & 48,8\end{array}$

